\title{
COVID-19 Pandemisinin Toplumsal Etkileri: Zenofobik Eğilimler ve Sonuçları
}

\section{Social Impacts of the COVID-19 Pandemic: Xenophobic Tendency and Their Consequences}

\author{
Faruk Bozdağ 1 (D)
}

\section{$\ddot{0 z}$}

Koronavirüs hastallğı-19 (COVID-19) pandemisi sürecinde, toplumlarda çeşitli alanlarda sorunlar yaşanmıştır. Özellikle sağlık ve ekonomi alanındaki sorunlar önemli noktalara ulaşmış ve bu alanlardaki çalışmalar yoğunlaşmıştır. Öte yandan pandeminin toplumda bireyler arasında psikososyal sorunları da artırdığı görülmüştür. Virüsün yayılmasılyla birlikte insanların yaşam koşulları değişmiştir. Alınan fiziksel mesafe önlemleri kapsamında yaşamları kısıllanmış ve bu durum çeşitli psikolojik sorunların ortaya çıkmasına neden olmuştur. Yaşam koşullarındaki olumsuzluklar ve maruz kalınan sorunlar, insanları günah keçisi aramaya yönlendirmiştir. Sonuç olarak toplumda yabancı olarak değerlendirilen göçmenlere yönelik olumsuz tutumlar yaygınlaşmaya başlamışıır. Yabancılara karşı korku, nefret ve ön yargı olarak değerlendirilen zenofobi artmıştır. Mevcut çalışmada COVID-19 pandemisi sürecinde zenofobik eğilimlere yol açan faktörler, zenofobik eğilimlerin etkileri ve zenofobik eğilimleri önlemeye yönelik çeşitli adımların değerlendirilmesi amaçlanmışıı. Bu amaçla ilgili literatür gözden geçirilmiştir. Toplumda zenofobik eğilimlerin yaygınlaşması, sosyal uyumun sağlanması konusunda önemli bir risk olarak değerlendirilmektedir. Bu nedenle zenofobik eğlimlerin önlenmesi gerekmektedir. Bu kapsamda pandemi sürecinde göçmenlere dair asıllsız bilgilerin ve ön yargıların önüne geçilmesi için gerekli adımlar atılıalıdır. Özellikle medyanın ve politikacıların etkisi dikkate alınmalıdır. Göçmenlerin yaşadığı sosyal ve ekonomik eşitsizlikler giderilmelidir. Toplumdaki sosyal ve adli kurumlara, eğitim ve sağlık hizmeti sunan kuruluşlara erişimleri kolaylaştııılmalıdır. Zenofobik eğilimlerin göçmenler üzerindeki olumsuz etkilerini azaltmak için etkin ruh sağlığı hizmeti sunulmalıdır.

Anahtar sözcükler: COVID-19, göçmenler, zenofobi, pandemi, sinofobi

\section{Abstract}

The Coronavirus disease-19 (COVID-19) pandemic process caused problems in various fields in societies. Particularly the problems in the field of health and economy reached a certain point, and studies in these areas have intensified. In addition, the pandemic also increased psychosocial problems among individuals in the society. With the spread of the virus, people's living conditions changed. Their lives were restricted due to the physical distancing measures taken, and this led to the occurrence of various psychological problems. The negativities in their living conditions and the problems they are exposed to led people to look for scapegoats. Therefore, negative attitudes towards migrants who are regarded as foreigners began to spread in the society. Considered as fear, hatred and prejudice towards foreigners, xenophobia increased. In the present study, it is aimed to evaluate the factors that lead to xenophobic tendencies, the effects of xenophobic tendencies and various steps to prevent xenophobic tendencies during the COVID-19 pandemic process. In this regard, the relevant literature has been reviewed. The spread of xenophobic tendencies in the society is seen as an important risk in ensuring social cohesion. Thus, xenophobic tendencies should be prevented. As such, necessary steps should be taken to prevent unfounded information and prejudices about migrants during the pandemic process. Particular attention should be paid to the influence of the media and politicians. Social and economic inequalities experienced by migrants should be eliminated. Their access to social and judicial institutions, and educational and healthcare establishment in the society should be facilitated. Effective mental health services should be provided in order to reduce the negative impacts of xenophobic tendencies on migrants.

Keywords: COVID-19, migrants, xenophobia, pandemic, sinophobia

1|istanbul Üniversitesi-Cerrahpaşa, İstanbul, Türkiye

$凶$ Faruk Bozdağ, İ stanbul Üniversitesi-Cerrahpaşa, Hasan Ali Yücel Eğitim Fakültesi, İstanbul, Türkiye faruk.bozdag@istanbul.edu.tr|0000-0002-9862-2697

Geliş tarihi/Received: 07.11.2020|Kabul tarihi/Accepted: 06.01.2021 | Çevrimiçi yayı/Published online: 03.06.2021 
COVID-19 pandemisi neredeyse dünya üzerindeki tüm ülkeleri yoğun bir şekilde etkisi altına almıştır (World Health Organization (WHO) 2020). Pandeminin etkileri, toplumsal, ekonomik, politik ve ruhsal olarak birçok alanda hissedilmektedir (Akat ve Karataş 2020, Banerjee ve Rai 2020). Açık bir şekilde yaygın bulaşıcı hastalıklar olarak tanımlanan pandemiler, tarihsel olarak politik ve ekonomik ilişkiler, dış müdahaleler, çatışma ve toplumda sosyal kontrolü sağlamaya yönelik endişelerle bağlantılı bir şekilde ele alınmıştır (Leach 2020). COVID-19 pandemisi, bir yandan devletlerin, toplumların ve farklı sosyo-ekonomik statüye mensup bireylerin karşılıklı olarak dayanışma içine girmesine ve birbirilerini desteklemesine katkı sağlarken diğer yandan özellikle göçmenlere karşı mevcut güvensizlik ve ayrımcılık kültürünü tetikleyen yaygın korku ve endişelere de neden olmuştur (International Organization for Migration (IOM) 2020a). Pandemi nedeniyle göçmenlere yönelik sosyal ve ekonomik eşitsizlikler artmış, göçmenler ayrımcıllğa maruz kalmış ve damgalanmıştır (IOM 2020b).

Kamusal alanlarda daha az görünür olmaları, tedavi ve önleme hizmetlerine erişim konusunda ayrımcılığa uğramaları, farklı ırk ve etnik kökenlerinden dolayı virüse karşı bağışıklıklarının olduğunun düşünülmesi veya virüsü yaymakla suçlanmaları gibi sebeplerle göçmenler, pandemi sürecini en ağır şekilde geçiren savunmasız gruplardan biri olarak görülmektedir (Broid 2020). Diğer birçok krizde olduğu gibi COVID-19 pandemisinde de göçmenler, yoğun bir şekilde olumsuz sonuçlarla karşı karşıya kalabilecek en hassas grubu oluşturmaktadır (Guadagno 2020, Runge 2020). Virüse karşı etkin önlemlerin alınması ve virüsün doğasının daha iyi anlaşılması, ırk, etnisite ve milliyetten bağımsız olarak herkesin dikkate alınmasını gerektirmektedir (Batasin 2020). Bununla birlikte göçmenlerin, pandeminin doğrudan ve dolaylı etkilerini daha yoğun bir şekilde deneyimledikleri göz ardı edilmemelidir (Guadagno 2020).

Göçmenlerin pandemi sürecinde maruz kaldıkları olumsuzlukların başında zenofobik eğilimler gelmektedir (Cheah 2020, Cheng 2020). Zenofobi (xenophobia), sözlükte diğer ülke insanlarından nefret etme ya da onlara karşı ön yargılı olma şeklinde geçmektedir (Oxford Dictionary 2020). Yunanca yabanc1 anlamındaki "xenos" ve korku anlamındaki "phobos" kelimelerinden oluştuğu için literatürde "yabancı korkusu" olarak kullanılmaktadır (Arogundade 2011). Zenofobi, göçmenlere ilişkin korku (Ortona 2017) olarak ele alınmakla birlikte yoğun antipati ve nefreti de kapsamaktadır (Tafira 2011). Grup dışındakilere yönelik korku, nefret ve aşağılama duygularının yol açtığı düşmanca tavırlar, zenofobi olarak ele alınmaktadır (Bozdağ 2020). Zenofobinin bir milliyete veya etnisiteye karşı ön yarg1 içermesi, genellikle kültürel/etnik veya irksal üstünlük varsayımına dayansa (American Psychiatric Association 2010) da zenofobi ve 1 rkçılık arasında çeşitli farklılıklar bulunmaktadır. Zenofobi, bilinmeyene karşı bir korku ve hoşlanmama durumuna işaret ederken ırkç1lık, belirli bir ırktan hoşlanmamayı simgelemektedir. Zenofobik eğilimleri olan biri grup dışındakilerden/farklı olandan hoşlanmazken, 1rkçı biri, kendi özelliklerini taşımayan (saç ve deri rengi, dili, etnik kökeni gibi) insanlara tahammül edememektedir (Kumar 2011).

Ev sahibi toplum üyeleri, kimliklerine ve sosyal statülerine karşı bir tehdit olarak 
algıladıkları için ve genel olarak güvenlik kaygılarından dolayı zenofobik eğilimler sergileyebilmektedir (Stafford 2020). Bir başka ifadeyle grup dışı bireylerin kimlik, değer, kültür ve sosyoekonomik statü bağlamında ev sahibi toplum üyeleri tarafindan bir tehdit unsuru olarak görülmesi zenofobik eğilimlere yol açabilmektedir (Canetti-Nisim ve ark. 2006). Bu tür eğilimler, göçmenlerin ev sahibi toplumla bütünleşmesini zorlaştırmakta, toplumun refahı ve gelişimi için çok önemli olan sosyal uyumu, olumsuz yönde etkilemektedir (Zubashvili 2020). Pandemi sürecinde göçmenlere karşı mevcut güvensizlik, ayrımcılık, korku ve endişelerin arttığı görülmektedir (Gover ve ark. 2020, IOM 2020a). Göçmenlerin enfeksiyondan kaçınma, yeterli sağlık hizmeti alma ve pandeminin ekonomik, sosyal ve psikolojik etkileriyle baş etme yetenekleri çeşitli faktörlerden etkilenmektedir. Bu faktörler; yaşam ve çalışma koşulları, kültürel ve dilsel çeşitliliklerinin dikkate alınmaması, sınırlı yerel bilgi ve ağları, ev sahibi topluluklardaki haklara erişimler konusundaki sorunlar ve hizmet sunumunda zenofobik eğilimler olarak ifade edilmektedir (Guadagno 2020).

Bilim insanları COVID-19 pandemisinin sağlığa etkileriyle yoğun bir şekilde ilgilenirken göçmenlere yönelik ön yargı ve zenofobik eğilimlerin yayılmasına yeteri kadar odaklanamamıştır (Zeng ve ark. 2020). Pandemi süreci, genellikle bilginin üretilmesi, aşı çalışmaları ve insanların hastalığa yakalanmasını önlemeye odaklanmayla karakterizedir. Bununla birlikte pandeminin sosyo-kültürel sonuçları çoğu zaman göz ardı edilmektedir. Oysaki zenofobik eğilimlerin yaygınlaşması, toplumda çeşitli grupların damgalanmasına, hedef alınmasına ve bu nedenle sağlık hizmetlerinin de uygun bir şekilde sunulamamasına neden olmaktadır (Batasin 2020). Zenofobik eğilimleri kapsamlı bir şekilde değerlendirebilmek için bazı hastalıkların ve sosyal koşulların korku ve ayrımcılığı nasıl körüklediğini ve hastalık nedeniyle toplumdaki çeşitli grupların damgalanmasının küresel kalkınma için de önemli bir zorluk olduğunu kabul etmek gerekmektedir (Das 2020). Bu doğrultuda bu araştırmada COVID-19 pandemisi sürecinde zenofobik eğilimlere yol açan faktörler, zenofobik eğilimlerin etkileri ve zenofobik eğilimleri önlemeye yönelik çeşitli adımlar değerlendirilmiştir.

\section{Pandemi sürecinde zenofobik eğilimlere yol açan faktörler}

Son yıllarda özellikle batı toplumlarında göçmenlere yönelik zenofobik eğilimlerin arttığ1 görülmektedir (Barni ve ark. 2020). Birçok batı ülkesinde (örn., ABD, İsveç, Almanya ve Fransa) aşırı sağcı ve göçmen karşıtı partiler ve politikacılar daha fazla destek görmektedir (Georgiadoua ve ark. 2018, Conneely 2019, Zubashvili 2020). Çeşitli toplumlarda zenofobik eğilimlere yol açan temel faktörler incelendiğinde ekonomi, göç hareketleri, kültürel tehdit alg1sı, politik dengesizlikler, dinsel doktrinler ve terörizmin ön plana çıtı̆̆g anlaşılmaktadır (Omuluabi 2008). Bununla birlikte geçmiş dönemlerde salgınların hemen ardından da zenofobik eğilimlerin arttığı görülmüştür. Özellikle viral salgınlar ölümcül olduğunda korku, çoğu zaman risk altındaki kişileri, suçu kendi ulusal, dini veya etnik kimliklerinin dişındaki bir "diğerine" veya bir gruba yüklemeye yönlendirmiştir (Muzzatti 2005). Tarih boyunca viral hastalıklar, genellikle salgınların ilk meydana geldiği yer veya bölgelerle ilişkilendirilmiştir. WHO, bu uygulamayı durdurmak ve böylece bu bölgelere veya bu bölgelerin insanlarına 
yönelik ön yargı ve zenofobik eğilimleri azaltmak için 2015 yılında çeşitli yönergeler çıkarmıştır (Zeng ve ark. 2020). Bu yönergeler, herhangi bir kültürel, sosyal, ulusal, bölgesel, mesleki ve/veya etnik grubu rahatsız etmekten kaçınmayı hedeflemiştir (WHO 2015). Damgalayıcı iletişimin önünde geçmek amacıyla hastalıkların adlandırılmasına yönelik bu yönergelere rağmen (WHO 2015) "İspanyol gribi”, "Meksika domuz gribi” gibi damgalayıc1 ifadelerin sıklıkla kullanıldığı görülmektedir. Bu tür damgalayıcı ifadeler, yabancılar ile belirli bir salgın arasında ilişkinin olduğunu öne sürerek zenofobik eğilimlerin artmasına neden olmaktadır (Hoppe 2018).

COVID-19 virüsü için kullanılan yanlış ve damgalayıcı ifadelerin önüne geçmek için sürekli bir çabanın olduğu bilinmektedir (Adalja 2020). Bununla birlikte COVID-19 olgularının artmasıyla özellikle ABD'de siyasi liderler ve toplumun bazı kesimleri tarafından "Çin virüsü”, "Kung-Flu”, “Çin koronavirüsü” ve "Wuhan virüsü” gibi terimlerin sıklıkla kullanıldığ görülmüştür (Reny ve Barreto 2020, Wardell-Ghirarduzzi 2020). Virüse ilişkin bu tarz adlandırmalar Asyalı topluluklara yönelik olumsuzlukların meşrulaştırılmasına, tedavi hizmetlerinin aksamasına ve bu toplulukların damgalanmasına neden olmuştur (Wardell-Ghirarduzzi 2020). Reny ve Barreto'nun (2020) yaptığ 1 çalışmayla pandeminin bu şekilde bir sosyal gruba bağlanmasının Asyalı topluluklara karşı olumsuz tutumları harekete geçireceği deneysel olarak da kanıtlanmıştır.

Virüs hakkındaki bilgilerin iletilmesinde kullanılan üslup ve dil, zenofobik eğilimlerin yaygınlaşmasına neden olduğu gibi önlenmesine de büyük katkılar sağlayabilmektedir (Stanford News 2019, Wardell-Ghirarduzzi 2020). Bununla birlikte mevcut durumda önlenmesinden ziyade göçmenlere yönelik olumsuz ifadelerle damgalamanın ve zenofobik eğilimlerin yaygınlaştığı anlaşılmaktadır (IOM 2020b). ABD'de COVID-19 olgularıyla bağlantılı bir şekilde Asyalılara ve Asya kökenli Amerikalılara yönelik ırkçı eylemlerin arttı̆̆ı, yaygın ön yargılar nedeniyle Asya toplumlarının sözlü ve fiziksel istismara karşı savunmasız hale geldiği görülmektedir (Batasin 2020, Yan ve ark. 2020). Benzer şekilde Avrupa'da da Asyalılara, İtalyanlara, Romanlara, gezginler ve diğer azınlık gruplarına yönelik zenofobik eğilimlerin ve ayrımcılığın arttığı belirtilmektedir. Bu gruplar virüsü yaymak ve virüse sebep olmak konusunda günah keçisi ilan edilmektedir (Hale 2020). Singapur'da da yerel halk ve göçmenler arasındaki gerilimlerin pandemi nedeniyle gün yüzüne çıktığ1 ve zenofobik eğilimlerin yükseldiği belirtilmektedir (Wong 2020).

Bangladeş'te Dakka'dan köyüne dönen 36 yaşındaki yetişkin bir adamın köydeki diğer insanlar tarafından COVID-19 olduğu şüphesiyle zenofobik eğilimlere maruz kalması nedeniyle intihar ettiği bildirilmektedir (Mamun ve Griffiths 2020). Benzer şekilde Hindistan'da 50 yaşındaki yetişkin bir adam, COVID-19 olduğuna dair yanlış inanç ve korku nedeniyle intihar etmiştir (Goyal ve ark. 2020). Ahuja ve ark. (2020) tarafindan Hindistan'da 600 katılımciyla yürütülen bir araştırma sonucunda Müslümanlara yönelik genel zenofobik eğilimlerin düşük olduğu, buna karşın COVID-19 pandemisiyle ilişkili zenofobik eğilimlerin ise yüksek olduğu saptanmıştır. Reny ve Barletto (2020) tarafindan ABD'de 4.311 kişiyle yapılan bir diğer araştırma sonucunda virüsle ilgili endişe, zenofobik eğilimler ve politik tercihlerin Asya karşıtı tutumlarla ilişkili olduğu belirlenmiştir. 
Dhanani ve Franz'ın (2020) ABD'de 1.451 katılımcıyla yürüttüğü araştırmada ise virüse ilişkin tarafsız bir bakış açısı yerine COVID-19 ile Çin arasında bağlantı kurmanın, Asyalı Amerikalılara yönelik olumsuz tutumları, kaynakların göçmenlerden ziyade Amerikalılar için kullanılmasına dair inançları ve zenofobik eğilimleri artırdığı ortaya çıkmıştır. Virüsün ekonomik etkilerinin yoğun bir şekilde vurgulanması, Asyalı Amerikalıların kaynaklar için birer tehdit olduğu inancını ve zenofobik eğilimleri daha da artırmaktadır.

Mevcut haliyle dünyada en fazla mülteci barındıran ülkelerden biri olan Türkiye'de COVID-19 pandemisi sürecinde doğrudan zenofobik eğilimlerin ele alındı̆̆1 herhangi bir çalışma olmamakla birlikte, bu süreçte mültecilerin deneyimlerine odaklanan çeşitli araştırmalar yürütülmüştür. COVID-19 pandemi sürecinden önce Türkiye'deki mültecilere yönelik faaliyetler temel koruma hizmetlerinden sosyal uyuma doğru yönelirken pandemiyle birlikte yeniden temel koruma hizmetleri ön plana çıkmıştır (Üstübici ve Karadağ 2020). Sı̆̆ınmacılar ve Göçmenlerle Dayanışma Derneği’nin (SGDD) (2020) 960'1 Suriyeli olmak üzere 1.162 mülteciyle yaptığı araştırmada mültecilerin çoğunun beslenme ve hijyen gereksinimlerini karşılamakta güçlük yaşadığı, kiralarını, faturalarını ve temel ihtiyaç malzemelerini edinmekte zorlandıkları saptanmıştır. Mülteci Destek Derneği (MUDEM) (2020) tarafindan 385 mülteci hanesinden toplanan verilerle yürütülen bir diğer araştırmada, mültecilerin \%91'inin COVID-19 pandemisinden ekonomik olarak etkilendiği, \%52'inin COVID-19 pandemisi sürecinde hastane randevuları, ilaç temini, raporların yenilenmesi gibi sağlık hizmetlerine yönelik yapılan güncellemeler hakkında bilgilerinin olmadığı belirlenmiştir. Benzer şekilde ReliefInternational'ın (2020) 879 Suriyeli mülteciyle yürüttüğü çalı̧̧mada mültecilerin \%87'sinin hane halkı içindeki birinin pandemi nedeniyle işini kaybettiğini bildirdiği, \%71'inin sağlık hizmetlerine erişemediği, \%81'inin ise karşılanması gereken acil ihtiyaçlarının bulunduğu saptanmıştır. Öte yandan COVID-19 pandemisi nedeniyle uygulanan sosyal mesafe önlemleri, mültecilerin sosyal uyumunu destekleyen en önemli unsur olan ev sahibi toplum ile etkileşimi oldukça azaltmıştır (MUDEM 2020). Sosyal temasla ev sahibi toplum üyelerinin zenofobik eğilimleri arasındaki olumsuz ilişki (Bozdağ 2020) göz önünde bulundurulduğunda bu durum endişe vericidir. Türkiye'de hassas ve kırılgan bir şekilde ilerleyen sosyal uyum konusu, COVID-19 pandemisi nedeniyle geriye gitme riski altındadır. COVID-19 pandemisi sürecinde bu riski daha da artırabilecek yanlış bilgi ya da haberlerin, ev sahibi toplum ve mülteci topluluk arasında sosyal gerginliğe neden olabilecek ayırımcı uygulamaların dikkatle ele alınması gerekmektedir (MUDEM 2020).

Göçmenlere yönelik zenofobik eğilimlerin artmasında, ev sahibi toplum üyeleriyle göçmenler arasındaki etkileşim düzeyi, kimlik ve milliyetçiliği içeren kültürel faktörler ve iş fırsatları ile var olan kaynaklara ilişkin ekonomik etkenler belirleyici olmaktadır (Nell 2008). Son yıllarda özellikle milliyetçilik akımlarının yükselmesiyle zenofobik eğilimler artmıştır (Barni ve ark. 2020, Alrababa’h ve ark. 2021). Pandemi sürecinde ise göçmenlere yönelik zenofobik eğilimleri tetikleyen önemli iki faktör olarak medya ve politikacıların etkisi ön plana çıkmaktadır. Medyadaki söylemler ve politikacıların pandemi sürecini planlama ve yürütme şekli ile bu süreçte kullandıkları ifadeler, toplumda göçmenlere yönelik tutum ve alg1lara yön vermektedir. 


\section{Medyanın etkisi}

Pandemi nedeniyle kısıtlanan bireyler, daha çok sosyal medya ve çevrimiçi uygulamalar aracılığıyla iletişimlerini sürdürmüştür (Teixeira da Silva 2020). Sosyal medya, web siteleri ve çeşitli uygulamalarla paylaşımların kolaylaşması, önceki dönemlere kıyasla gönderilerin daha hızlı bir şekilde ve daha geniş kitlelere ulaşmasını sağlamıştır. Bununla birlikte internet aracılığıyla bilginin hızlı bir şekilde yayılması, yanlı̧̧ bilgi dalgalarının önüne geçmekte çeşitli zorlukların yaşanmasına da neden olmaktadır (Somvichian-Clausen 2020, Teixeira da Silva 2020). Medyanın salgın hastalıklarla ilgili olarak abartılar yapması veya güvence sunması, insanların hastalığa ilişkin risk algılarını artırabilmekte veya azaltabilmektedir (Fung ve ark. 2014).

Pandemiyle ilgili bilgileri gerçek zamanlı olarak ve dijital medya aracılığıyla aktarmak, göçmenler de dahil olmak üzere kısıtlamaların olduğu bu dönemde pek çok kişi için önemli bir yaşam deneyimi olmuştur. Bununla birlikte, bu tür medya kaynakları aynı zamanda yanlış bilgilendirme, söylenti ve doğrudan nefreti yaymak için bir araç haline gelebilmektedir. Nitekim COVID-19 pandemisi sürecinde medyada zenofobik söylemler artmıştır (IOM 2020a). Irkçılığı normalleştiren iletişim tarzları, toplumdaki korkuların yaygınlaşmasına ve gerilimin tırmanmasına neden olmuştur (Asmelash 2020). Bu anlamda haber başliklarının etkileri dikkate alınmalıdır. Haber başlıkları insanların benimsediği tutumlar üzerinde güçlü bir etkiye sahiptir. Güvenilir kaynaklar ve bağlamla bağlantısı olmayan sahte haberler, zenofobiyi tetiklemektedir (Noel 2020). ABD'de medyanın COVID-19 pandemisine ilişkin tepkisi genelde sansasyonel ifadelerin kullanımı, yanlış bilgilerin aktarılması ve zenofobik manşetlerin sunulması şeklinde olmuştur. Yanlış anlaşılmalarla birlikte "öldürücü virüs”, “ölümcül virüs” ve "Wuhan virüsü” gibi başlıkların kullanımı, ön yarg1, ayrımcılık ve zenofobik eğilimlere yol açan korku ve paniği artırmıştır (Noel 2020). Bunların yanı sıra çevrimiçi iletiler ve sosyal medya gönderileri, art niyetli bir şekilde dolaştırılarak göçmenlere yönelik aşağılayıcı yorumlar ve şiddet içeren tehditler yayılmaktadır. Yeni nefret olayları, sahte haberlerin ve/veya yanlış bilgilerin yer aldığı dijital haber kaynakları ve sosyal medya da dahil olmak üzere ana akım medyada özellikle belirginleşmiştir (IOM 2020a).

Schild ve arkadaşları (2020) COVID-19 pandemisi sürecinde Twitter ve 4chan'dan beş ay boyunca topladıkları verilerle sinofobiye (sinophobia, Çin ve Çin kültürüne duyulan nefret) ilişkin söylemleri analiz etmiştir. Analizler sonucunda COVID-19 pandemisiyle birlikte ayrımcı bazı yeni kavramların türediği (Çin virüsü, kung flu gibi) ve COVID-19 pandemisinin sinofobinin yükselmesine neden olduğu belirlenmiştir. COVID-19 pandemisi sürecinde nefret söylemi ve zenofobik söylemlerin arttığ1 görülmüştür. Benzer şekilde ABD'de New Jersey merkezli bir kuruluş olan Network Contagion Research Institute (NCRI) (2020) tarafindan yürütülen çalışmada sosyal medya platformlarında Çin toplumuna ilişkin zenofobik söylemlerin keskin bir şekilde arttı̆̆ı saptanmıştır. Ziems ve arkadaşları (2020) tarafindan yürütülen bir diğer araştırmada Asya karşıtı nefret söylemi ve bu söylemlerin yayılması 30 milyondan fazla tweet incelenerek analiz edilmiştir. Analizler sonucunda COVID-19 pandemisi sürecinde nefret söyleminin yükseldiği, nefret söylemine 
başvuranlarla karşıt nefret söylemine başvuranların yoğun bir etkileşimde oldukları belirlenmiştir. Nefretin bulaşıcı olduğu ve nefret içerikli söylemlere maruz kalındıktan sonra daha da arttığı belirtilmiştir. Sonuç olarak COVID-19 pandemisi sürecinde medya kanalları aracılığıyla zenofobik eğilimlerin arttığı anlaşılmaktadır.

\section{Politikacıların etkisi}

COVID-19 krizi, yalnızca halka korku aşılamakla kalmamış, aynı zamanda dinamik bir şekilde politikaya yön veren korkunun etkisini gün yüzüne çıkarmıştır (Degerman ve ark. 2020). Genel olarak salgınlar korku yaratmakta ve korku; 1rkçılı̆̆ın ve zenofobik eğilimlerin yaygınlaşmasında temel bir bileşen olarak rol oynamaktadır. Bu bağlamda COVID-19 pandemisi de toplumlarda sosyal ve politik kırılmaları ortaya çıkarmış, marjinalleştirilmiş gruplara karşı 1rkçı ve ayrımcı tepkilere neden olmuştur. Siyasi liderlerin çoğu, pandemi sürecini kötüye kullanarak ırk ayrımcılığının artmasına ve göçmen karşıtı söylemlerin yaygınlaşmasına neden olmuştur (Devekumar ve ark. 2020).

Salgın hastalık sürecinde zenofobik eğilimlerin yaygınlaşmasında politikacıların söylemlerinin önemli etkileri bulunmaktadır. Kanada ve ABD'de SARS virüsüne ilişkin 5.638 politik tepkinin karşılaştırmalı olarak analiz edildiği bir araştırmanın sonucunda, çok kültürlü toplumların yanı sıra geniş politik alt sistemleri de olumsuz yönde etkileyen zenofobik söylemlerin yaygın olduğu belirlenmiştir (Baker 2007). Benzer şekilde günümüzde COVID-19 pandemisi sürecinde ABD'de hükümet liderlerinin kullandıkları uygunsuz dilin toplumdaki gerilimleri artırdığı görülmektedir (Batasin 2020). ABD Eski Başkanı Donald Trump'ın COVID-19'u Çin virüsü olarak adlandırması, öte yandan İtalya eski Başbakan Yardımcısı Matteo Salvini’nin COVID-19'u yanlış bir şekilde Afrikalı sı̆̆ınmacılarla ilişkilendirerek sınırların kapatılması çağrısında bulunması, toplumda olası çatı̧̧maları tetiklemiştir (Devekumar ve ark. 2020). Renny ve Barreto'nun (2020) 4.311 kişiyle yürüttükleri araştırma soncunda Asya kökenli Amerikalılara yönelik olumsuz tutumların, virüsle ilgili endişeler ve zenofobik davranışlarla ilgili olduğu kadar politik tercihlerle de ilişkili olduğu belirlenmiştir. Bireylerin benimsedikleri politik tutumlar, Asyalılara karşı olumsuz davranışları harekete geçirebilmektedir.

Çeşitli açık ve örtük politikalar nedeniyle, birçok yerde göçmenler pandemi sırasında sağlık hizmetlerine erişmeye çalışırken farklı engellerle karşılaşmıştır (IOM 2020b). Avrupa ülkelerinde Romanlar, mülteciler, sığınmacılar ve göçmelere yönelik kurumsal ırkçılı̆̆ın, hukuki uygulamalardaki ayrımcılığın ve kolluk kuvvetlerinin hesap verilebilirlikten uzak bir şekildeki güç kullanımının, endişe verici boyutlarda olduğu belirtilmiştir (Amnesty International (AI) 2020). Göçmenler, beyaz olmayanlar ve düşük sosyoekonomik statüdeki bireyler, pandeminin olumsuz sonuçlarına orantısız bir şekilde daha fazla maruz kalmış, sağlık hizmetlerine erişimde ciddi sınırlılıklar yaşamıştır (Devekumar ve ark. 2020). Bazı ülkeler/bölgelerde (örn., ABD, İtalya, Yunanistan, İspanya, Tayland, Malezya) COVID-19 pandemisi nedeniyle uygulanan hareket kısıtlamaları belirli göçmen toplulukları hedef almıştır (AI 2020, Guadagno 2020, IOM 2020b). Göçmenlere yönelik bu tür katı kısıtlamalar, temel bakım ve hizmetlere erişimlerini engellemiştir (IOM 2020b). Ayrıca birçok 
ülkenin pandemi nedeniyle sınırlarını kapatması, ulus devlet düşüncesini ve vatandaşların ayrıcalıklarını yeniden gündeme getirmiştir. Sınırların kapatılması ve vatandaşlığın ön plana çıkması, bazı göçmenlerin eve dönüşünü mümkün kılmakla birlikte çoğu göçmen, daha güvencesiz bir statüye yerleştirilmiştir (Kollender ve Nimer 2020). Bu tarz uygulamalar ve genel olarak politikacıların söylemleri dikkate alındığında zenofobiyle etkili bir şekilde mücadele etmenin, onu üreten ve sınırlayan sistemleri incelemeye ve iyileştirmeye bağlı olduğu anlaşılmaktadır (Neol 2020).

\section{Pandemi sürecinde zenofobik eğilimlerin sonuçları}

COVID-19 nedeniyle artan zenofobik eğilimlere ilişkin çeşitli araştırma sonuçları, sosyal uyumun sağlanması ve pandemi sürecinin etkin bir şekilde yürütülmesiyle ilgili endişelere işaret etmektedir. Pandeminin başlangıcından 5 Ağustos 2020'ye kadar Amerika Birleşik Devletleri'nde 2.583 ayrımcı ve zenofobik olay belgelemiştir (Jeung ve ark. 2020). Çeşitli ülkelerden gelen raporlar, ayrımcı ve zenofobik davranışların gıda güvensizliğine ve göçmenlerin kendi ülkelerine dönmelerine neden olduğunu göstermektedir (IOM 2020b). ABD'de zenofobik eğilimlerin yükselmesiyle Asyalı Amerikalıların ülkelerine dönmelerine dair talepler de artmış ve bu durum toplumda Asyalı Amerikalıların daha fazla dışlanmalarına neden olmuştur (Cheng 2020). Asyalı Amerikalılar, fiziksel saldırı, sözlü taciz, üzerine öksürülme, dükkan ve restoranlardan kovulma, işyerlerinde ayrımcılık ve vandalizm gibi ciddi sorunlar yaşamaktadır (Cheung ve ark. 2020). Los Angeles ve New York’ta metro istasyonlarında Asya kökenli Amerikalıların sözlü ve fiziksel tacize uğradıkları (Batasin 2020) ABD'de Asya kökenli Amerikalılara yönelik iki hafta içinde 1.135 sözlü taciz, utandırma ve fiziksel saldırı olayının gerçekleştiği (Redden 2020) bildirilmektedir. Malezya'da yürütülen bir başka çalışmada COVID-19 pandemisi nedeniyle Rohingyalar'a yönelik zenofobik eğilim ve ırkçılı̆̆ın arttığı belirlenmiştir. Bu durum, hem sosyal medyada hem de hükümet politikalarında Rohingyalar'a karşı artan nefret söylemine ilişkin raporlarla desteklenmektedir (Mixed Migration Centre (MMC) 2020). Polonya'da Asyalı üniversite öğrencileriyle yapılan bir araştırmada COVID-19 pandemisinin öğrencilere yönelik zenofobik eğilimleri tetiklediği saptanmıştır. Öğrencilerin \%61,2'si ön yargıya maruz kaldıklarını, \%47,1'i bu ön yargılı tutumların toplu taşıma ve sokakta meydana geldiğini belirtmiştir. Asyalı öğrencilere yönelik gösterilen tepkilerin; uzaklaşmak, otobüste koltuk değiştirmek, güvenli mesafeyi korumak, ağzı ve burnu kapatmak, yargılayıcı yüz ifadeleri takınmak, parmakla işaret etmek ve fısıltı halinde konuşmak, tükürmek, bira şişesi firlatmak ve saldırgan bir dil kullanmak şeklinde olduğu saptanmıştır (Rzymski ve Nowicki 2020). Bir başka çalışmada Çin'deki katılımcıların \%90'ının Hubei eyaletinden gelen kişilere karşı varlıklarını yerel yetkililere bildirmek, onlardan kaçınmak ve onları topluluklarından aktif olarak çıkarmak gibi ayrımcı tavırlar sergiledikleri belirlenmiştir (He ve ark. 2020).

Pandemi sürecinde özellikle Asyalılara yönelik sözlü ve fiziksel saldırıların artmaya devam edebileceğine dair endişeler sürmektedir (American Hospital Association (AHA) 2020). Toplumda korku ve yanlış bilgilendirme nedeniyle Asyalı topluluklara yönelik 1 rkçı eylemlerin artması, bu toplulukların fiziksel sağlığının yanı sıra ruhsal sağlığını da riske 
atmaktadır (Cheah ve ark. 2020, Cheng 2020, Li 2020). Ön yarg1 ve ayrımcilıkla birlikte bireylerde duygusal ve fiziksel örselenmeler yaşanabilmektedir. Anksiyete ve depresyon, kişisel güvenlik endişesi ve fiziksel sağlığın kötüye gidişi gibi sorunlar görülebilmektedir. Ayrımcı tutumlar ayrıca kronik strese, hızlı yaşlanmaya ve sağlık sistemine ilişkin güvensizliğe yol açabilmektedir (AHA 2020). Irkçlığa ve ayrımcılığa maruz kalan Asyalı gençlerin ve genç yetişkinlerin benlik saygıları düşmekte, vücut imajı ve fenotipik özellikleri hakkındaki öz farkındalıkları olumsuz yönde etkilenmekte, hoşnutsuzluk ve utanç duyguları artmaktadır (Cheng 2020). Ayrıca pandemi döneminde okulların kapatılması ve çevrimiçi süreçlerin uygulanmaya konmasında göçmenlerin yeterince dikkate alınmaması, ruhsal sorunların yanı sıra eğitsel sorunların da yaşanmasına neden olmaktadır (Kollender ve Nimer 2020).

COVID-19 pandemisi nedeniyle zenofobik eğilimlerin artması söz konusu gruplara ilişkin algıları olduğu kadar tedavi hizmetlerini de etkilemektedir (Batasin 2020). Çin kökenli Amerikalı ebeveyn ve çocuklarının pandemi nedeniyle ırkçılığa ve ırkçı ayrımcılı̆̆a uğradıkları, sağlık hizmetlerinin sunumunda sinofobiye maruz kaldıkları belirlenmiştir (Cheah ve ark. 2020). Tunus'taki çeşitli göçmen gruplarından oluşan 178 kişiyle yapılan çalışma sonucunda göçmenlerin büyük bir bölümünün pandemi sürecinde ayrımcılık ve ırkçılık korkusu nedeniyle sağlık sistemine erişimde zorluklar yaşadığı belirlenmiştir. Sağlık sistemine erişim konusunda yaşanan zorlukların ötesinde Tunuslu göçmenler, COVID olgularının bildirilmesinden bu yana zenofobik eğilimlerin arttığını ve bunun günlük yaşamlarına çok yönlü olarak yansıdığını bildirmiştir (MMC 2020b). ABD'de hastanelerde bazı hastaların Asyalı hizmet sağlayıcılarını sözlü olarak taciz ettiği ve bakımı reddettikleri görülmüştür. Bazı Asyalılar ve Asya kökenli Amerikalılar, hem kamusal alanlarda hem de sağlık sistemi içinde ayrımcılık korkusuyla yardım arayamayabileceğini belirtmiştir (AHA 2020). Dahas1, göçmenler, özellikle de belgeleri olmayanlar, kimlik tespiti ve bildirimde bulunma korkusu nedeniyle hastanelerden kaçınmakta ve sonuç itibariyle hastalığın ilerlemesi ve daha geç bir dönemde tespit edilmesi söz konusu olmaktadır (Devekumar ve ark. 2020). Durum Türkiye açısından değerlendirildiğinde benzer şekilde göçmenlerin dil engeli, güvenilir bilgi eksikliği ve pozitif teşhis konulduğunda işlerini kaybetme korkusuyla hastanelere gitmekten kaçındıkları belirtilmektedir (Üstübici ve Karadağ 2020). Bu durum toplulukları riske atmaktadır (AHA 2020).

\section{Tartışma}

COVID-19 pandemisinde uygulanan fiziksel mesafe önlemleri ve çeşitli kısıtlamalar, insanlar arasındaki etkileşimlerin azalmasına yol açmıştır. İnsanlar arasındaki temasın süresini ve sıklığını azaltmak, çatışmaya ve uyumsuzluğa neden olabilmektedir (Teixeira da Silva 2020). Nitekim pandemi sürecinde zenofobik eğilimlerin yaygınlaştığı ve toplumda göçmenlere yönelik ırkçı ve ayrımcı davranışların yoğun bir şekilde sergilendiği yukarıda sunulan çeşitli araştırma sonuçlarıyla ortaya konmuştur. Dolayısıyla toplumda zenofobik eğilimlerin önlenmesine yönelik çeşitli adımların atılması gerektiği anlaşılmaktadır. Zenofobik eğilimlerin önüne geçmek, pandemi sürecinin daha etkin bir şekilde yürütülmesine önemli katkılar sağlayacaktır. 
Nefret dolu söylemleri, taciz ve fiziksel saldırıları içeren çok sayıda zenofobik olayda kanıtlandığı gibi dezavantajlı durumları gidermek ve eşitsizlikleri azaltmak için pandemi sürecindeki planlamada doğru bilgiye dayalı ve etkili iletişim stratejilerinin kullanımı hayati bir önem taşımaktadır (Lee ve ark. 2008). Bu anlamda ulaşılan bilgilerin etkin bir şekilde sorgulanması gerekmektedir. Kaynakların güvenilirliğini değerlendirmek için bilginin güncelliği, bilginin önemi, bilginin kaynağı, bilginin güvenilirliği ve doğruluğu ve bilginin var olma nedeni kapsamlı bir şekilde değerlendirilmelidir (Blakeslee 2004).

Sosyal medya platformları COVID-19 ile ilgili olarak ırkçılığı teşvik edebilecek, yanlış olduğu saptanan içeriklerin bildirilmesini ve kaldırılmasını kolaylaştırmalıdır. Kaldırılan içeriklerin tekrar paylaşılması durumunda bireylere içeriğin yanlış olduğuna dair bilgilendirmeler yapmalıdır (Chiu ve Chuang 2020). Medyada bilginin sunumuna özel önem verilerek halk arasında güven ve şeffaflık tesis edildiğinde, halk sağlığ1 yetkilileri, eğitim yetkilileri ve siyasi liderler, sosyal, ekonomik ve kültürel eşitlik için hayati önem taşıyan farklılıkları çözmek ve toplu karar alma süreçlerini iyileştirmek için önemli firsatlara sahip olacaktır (Noel 2020). Güvenilir kaynakların belirlenmesi, yanlış bilgi yayabilecek web sitelerinin, blogların ve sosyal medya sitelerinin olumsuz etkilerini bertaraf edebilecektir (Batasin 2020). Bu doğrultuda politikacıların ve medyanın söylemlerine dikkat etmelerinin ötesinde pandemi sürecinde bilginin aktarımı konusunda etkili planlar üretmeleri gerekmektedir.

COVID-19 pandemisi karşısında sağlık sistemlerinin yetersiz kalması, sunulan sağlık hizmetlerinde eşitsizliklere yol açmıştır. Bu eşitsizliklerin sonucu olarak da damgalama, ayrımcılık, ırkçılık ve adaletsizlik gibi kırılgan sosyal sorunlar yeniden gündeme gelmiştir (Teixeira da Silva 2020). Dolayısıyla sosyal sorunların önüne geçebilmek adına sağlık hizmetlerinde düzenlemelerin yapılması gerekmektedir. Öte yandan sağlı̆̆ın korunması, sağlık hizmetlerindeki düzenlemelere bağlı olduğu kadar sosyal içerme, adalet ve dayanışma kültürünün yaygınlaştırılmasına da bağlıdır. Bu faktörlerin yokluğunda eşitsizlikler büyümekte ve günah keçisi aranmaya devam edilmektedir (Devekumar ve ark. 2020).

\section{Sonuç}

Pandemi sürecince zenofobik eğilimleri önlemeye yönelik adımlar için Uluslararası Göç Örgütünün sunduğu çerçeve doğrultusunda çeşitli öneriler sunmak mümkündür. Bunlar şöyledir (IOM 2020a):

a. Nefret suçuna ilişkin yasal ve politik çerçeveler geliştirerek bunları etkin bir şekilde uygulamak.

b. Çevrimiçi forumlarda zenofobik söylemleri aktif bir şekilde ele almak.

c. İnsanlara saygı duyan ve onları güçlendiren tüm iletişim kanallarında kanıta dayalı ve damgalanmayan bir dili teşvik etmek.

d. Ön yargıyı azaltmak ve sosyal uyumu teşvik etmek için toplum merkezli yaklaşımları güçlendirmek. 
e. Kurtarma planları dahilinde ön yargıyı azaltma ve ayrımcılıkla mücadele önlemleri geliştirmek ve güçlendirmek.

Pandemi döneminde zenofobik eğilimlerin göçmenlerde ayrıca ruhsal sorunlara da yol açtığ1 göz önünde bulundurulduğunda, ruh sağlığ1 çalışanlarının bu konuda farkındalık sahibi olmaları gerektiği anlaşılmaktadır. Ruh sağlığı çalı̧̧anları zenofobik eğilimler ve ruh sağllğı üzerindeki etkilerini etkin bir şekilde değerlendirmelidir (Cheng 2020). Bir yandan toplumdaki zenofobik olayların engellenmesi ve azaltılması için damgalama ve 1 rkçılık karşıtı tutumlar sergilenirken diğer yandan göçmenlerin zenofobik eğilimlerle başa çıkmaya dair bilgi ve becerilerinin geliştirilmesi hedeflenmelidir. Ruh sağlığı çalışanları, hak savunuculuğu bağlamında rol ve sorumluluklarını pekiştirmelidir. Bu kapsamda göçmenlerin pandemi sürecinde sağlık hizmetleri başta olmak üzere sosyal, eğitim ve adalet hizmetlerinden etkin bir şekilde yararlanmaları için yönlendirici olmalıdırlar.

Araştırmacılar açısından değerlendirildiğinde, Türkiye'de COVID-19 pandemisi sürecinde göçmenlerin maruz kaldıkları zenofobik tutumlara dair çalışmaların olmaması, bu alandaki boşluğun doldurulması gerektiğine işaret etmektedir. Dünyada en fazla göçmen barındıran bir ülke olarak Türkiye'de, göçmenlere yönelik zenofobik eğilimlerin incelenmesi, toplumsal olarak COVID-19 pandemisinin daha etkin bir şekilde atlatılmasına katkı sağlayacaktır. Literatürde COVID-19 pandemisi sürecinde zenofobik eğilimlere yol açan faktörler arasında sıklıkla medya ve politikacıların etkisi ön plana çıkmaktadır. Göçmenlerin kendisinden ve ev sahibi toplum üyelerinden toplanacak nitel ve nicel verilerle, zenofobik eğilimlere yol açan farklı faktörlerin belirlenmesi, böylece toplumdaki zenofobik eğilimlerin azaltılmasına yönelik müdahale çalışmalarının geliştirilmesi mümkün olabilir. Genelde ırkçılık ve milliyetçiliğin, zenofobik eğilimleri tetiklediği bilinmektedir. COVID-19 pandemisi sürecinde 1 rkçılık ve milliyetçiliği etkileyen etmenler ve bunların zenofobik eğilimlerle ilişkileri ele alınabilir.

\section{Kaynaklar}

Adalja AA (2020) COVID-19: WH0 names disease caused by novel coronavirus. https://www.healio.com/infectiousdisease/emergingdiseases/news/online/\%7B1cca9ae9-7191-498b-9758-637eab141b71\%7D/covid-19-who-names-disease-caused-bynovelcoronavirus (Accessed 15.09.2020).

Ahuja KK, Banerjee D, Chaudhary K, Gidwani C (2020) Fear, xenophobia and collectivism as predictors of well-being during Coronavirus disease 2019: An empirical study from India. Int I Soc Psychiatry, doi: 10.1177/0020764020936323.

Akat M, Karataş K (2020) Psychological effects of COVID-19 pandemic on society and its reflections on education. Turkish Studies, 15:1-13.

Alrababa'h A, Dillon A, Williamson S, Hainmueller J, Hangartner D, Weinstein J (2021) Attitudes toward migrants in a highly impacted economy: Evidence from the Syrian refugee crisis in Jordan. Comp Polit Stud, 54:33-76.

AHA (American Hospital Association) (2020) COVID-19: Acknowledging and addressing racism and xenophobia. https://www.aha. org/system/files/media/file/2020/05/COVID-19_Xenophobia_Resource.pdf (Accessed 10.09.2020).

American Psychiatric Association (2010) Xenophobia, Immigration, and Mental Health. Washington DC, American Psychiatric Association.

Al (Amnesty International) (2020) Policing the Pandemic: Human Rights Violations in the Enforcement of COVID-19 Measures in Europe. London, Amnesty International.

Arogundade 0T (2011) Xenophobia: Carl Jung perspective. IFE Psychologia, 16:167-172.

Asmelash L (2020) UC Berkeley faces backlash after stating 'xenophobia' is 'common' or 'normal' reaction to coronavirus. https:// edition.cnn.com/2020/02/01/us/uc-berkeley-coronavirus-xenophobia-\%20trnd/index.html (Accessed 12.09.2020). 
Baker DL (2007) Differential definitions of fear and forgiveness: The case of SARS in North America. International Journal of Public Administration, 30:1641-1656.

Banerjee D, Rai M (2020) Social isolation in COVID-19: The impact of loneliness. Int J Soc Psychiatry, 66:525-527.

Barni D, Cavazza N, Russo S, Vieno A, Roccato M (2020) Intergroup contact and prejudice toward immigrants: A multinational, multilevel test of the moderating role of individual conservative values and cultural embeddedness. Int J Intercult Relat, 75:106-117. Batasin SJA (2020) Combating xenophobia in the COVID-19 pandemic: The importance of health literacy. Inquiries Journal, 12:7.

Blakeslee S (2004) The CRAAP test. LOEX Quarterly, 31:6-7.

Bozdağ F (2020) Xenophobia and social contact in university students. International Journal of Education \& Literacy Studies, 8:87-97. Broid G (2020) Xenophobia during Coronavirus pandemic: Attitudes towards immigrants and ethnic groups. Negev, Ben Gurion University of the Negev.

Canetti-Nisim D, Halperin E, Hobfoll SE, Johnson RE (2006) Xenophobia towards Palestinian citizens of Israel among Russian Immigrants in Israel: Heightened by failure to make gains in a new democratic society. Helen Kellogg Institute for International Studies, Working paper 327.

Cheng HL (2020) Xenophobia and racism against Asian Americans during the COVID-19 pandemic: Mental health implications. Journal of Interdisciplinary Perspectives and Scholarship, 3:3.

Cheah CS, Wang C, Ren H, Zong X, Cho HS, Xue X (2020) COVID-19 racism and mental health in Chinese American families. Pediatrics, 146:1-10.

Cheung H, Feng Z, Deng B (2020) Coronavirus: What attacks on Asian reveal about American identity. https://www.bbc.com/news/ world-us-canada- 52714804 (Accessed 15.09.2020).

Chiu 0, Chuang P (2020) COVID-19 coronavirus racism incident report. www.asianaustralianalliance.net (Accessed 15.09.2020).

Conneely A (2019) Effects of frequency of contact and group salience on attitudes towards immigrants (Bachelor's thesis). Dublin, National College of Ireland.

Das M (2020) Social construction of stigma and its implications - observations from COVID-19. Soc Sci Humanit Open, doi: 10.2139/ ssrn.3599764.

Degerman D, Flinders M, Johnson MT (2020) In defence of fear: COVID-19, crises and democracy. Crit Rev Int Soc Political Philos, doi: 10.1080/13698230.2020.1834744.

Devakumar D, Shannon G, Bhopal SS, Abubakar I (2020) Racism and discrimination in COVID-19 responses. Lancet, 395:1194.

Dhanani LY, Franz B (2020) Why public health framing matters: An experimental study of the effects of COVID-19 framing on prejudice and xenophobia in the United States. Soc Sci Med, 269:113572.

Fung ICH, Tse ZTH, Cheung CN, Miu AS, Fu KW (2014) Ebola and the social media. Lancet, 384:2207.

Georgiadou V, Rori L, Roumanias C (2018) Mapping the European far right in the 21st century: A meso-level analysis. Electoral Studies, 54:103-115.

Gover AR, Harper SB, Langton L. (2020) Anti-Asian hate crime during the COVID-19 pandemic: Exploring the reproduction of inequality. Am J Crim Justice, 45:647-667.

Goyal K, Chauhan P, Chhikara K, Gupta P, Singh MP (2020) Fear of COVID 2019: First suicidal case in India! Asian J Psychiatr, 49:101989. Guadagno L (2020) Migrants and the COVID-19 Pandemic: An Initial Analysis. Migration Research Series, 60. Geneva, International Organization for Migration.

Hale S (2020) COVID-19: National Equality Bodies Report Impacts on Equality and Share Their Responses to The Coronavirus Pandemic. Brussels, Equinet.

He J, He L, Zhou W, Nie X, He M (2020) Discrimination and social exclusion in the outbreak of COVID-19. Int J Environ Res Public Health, 17:2933.

Hoppe T (2018) "Spanish flu": When infectious disease names blur origins and stigmatize those infected. Am J Public Health, 108:1462-1464.

IOM (International Organization for Migration) (2020a) Countering xenophobia and stigma to foster social cohesion in the COVID 19 response and recovery. https://www.iom.int/sites/default/files/documents/countering_xenophobia_and_stigma_130720.pdf (Accessed 15.09.2020).

IOM (International Organization for Migration) (2020b) Understanding the migration \& mobility implications of COVID-19. https:// www.iom.int/sites/default/files/documents/covid-19_analytical_snapshot_29_stigmatization_and_discrimination_update.pdf (Accessed 15.09.2020). 
Jeung R, Popovic T, Lim R, Lin N (2020) Anti-Chinese rhetoric employed by perpetrators of Anti-Asian hate. https://a1w.90d.myftpupload. com/wp-content/uploads/2020/10/Stop_AAPI_Hate_Anti-China_Rhetoric_Report_201011.pdf (Accessed 15.09.2020).

Kollender E, Nimer M (2020) Long-Term Exclusionary Effects of COVID-19 for Refugee Children in the German and Turkish Education Systems: A Comparatıve Perspectıve. Istanbul, Istanbul Policy Center.

Kumar M (2011) Difference between xenophobia and racism. http://www.differencebetween.net/language/difference-betweenxenophobia-and-racism/ (Accessed 15.12.2020).

Leach M (2020) Echoes of Ebola: Social and political warnings for the COVID-19 response in African settings. (Accessed 15.10.2020).

Lee C, Rogers WA, Braunack-Mayer A (2008) Social justice and pandemic influenza planning: The role of communication strategies. Public Health Ethics, 1:223-234.

Li S (2020) "I don't scare easily, but I am afraid": The dangers of being Asian American right now. https://www.cosmopolitan.com/ politics/a31810912/anti-asian-racism-coronavirus/ (Accessed 15.09.2020).

Mamun MA, Griffiths MD (2020) First COVID-19 suicide case in Bangladesh due to fear of COVID-19 and xenophobia: Possible suicide prevention strategies. Asian J Psychiatr, 51:102073.

Mixed Migration Centre (2020a) Understanding the impact of COVID-19 on Rohingya and Bangladeshis in Malaysia. http://www. mixedmigration.org/wp-content/uploads/2020/07/124_covid_snapshot_Asia.pdf (Accessed 15.09.2020).

Mixed Migration Centre (2020b) Refugees' and migrants' access to health services in Tunisia: A focus on discrimination and COVID-19. https://reliefweb.int/sites/reliefweb.int/files/resources/098_covid_snapshot_NA.pdf (Accessed 15.09.2020).

MUDEM (2020) COVID-19 Krizi Sürecinde Türkiye'deki Mültecilerin Durum Analizi. Ankara, Mülteci Destek Derneği.

Nell I (2009) The tears of Xenophobia: Preaching and violence from a South African perspective. Practical Theology in South Africa, 24:229-247.

NCRI (Network Contagion Research Institute) (2020) Weaponized Information Outbreak: A case study on COVID-19, Bioweapon Myths, and the Asian Conspiracy Meme. New Brunswick, NJ, The Miller Center for Community Security at Rutgers University.

Noel TK (2020) Conflating culture with COVID-19: Xenophobic repercussions of a global pandemic. Soc Sci Humanit Open, 2:100044. Omoluabi PF (2008) Psychological foundation of xenophobia. IFE Psychologia, 16:53-71.

Ortona G (2017) Xenophobia is really that: A (rational) fear of the stranger. Mind and Society, 16:37-49.

Oxford Dictionary (2020) Definition of xenophobia in English. http://www.oxforddictionaries.com/definition/english/xenophobia (Accessed 15.12.2020).

Redden $\mathrm{E}$ (2020). Scholars confront coronavirus-related racism in the classroom, in research and in community outreach. https://www. insidehighered.com/news/2020/04/02/scholars-confront-coronavirus-related-\%20racism-classroom-research-and-community (Accessed 15.10.2020).

Relief International (2020) Impact of the COVID-19 outbreak on Syrian refugees in Turkey. https://reliefweb.int/sites/reliefweb.int/ files/resources/76504.pdf (Accessed 15.12.2020).

Reny TT, Barreto MA (2020) Xenophobia in the time of pandemic: Othering, anti-Asian attitudes, and COVID-19. Polit Groups Identities, doi: $10.1080 / 21565503.2020 .1769693$.

Runge J (2020) What will be the impact of COVID-19 on public attitudes to immigration? Economics observatory. https://www. coronavirusandtheeconomy.com/question/what-will-be-impact-covid-19-public-attitudes-immigration (Accessed 15.10.2020).

Rzymski P, Nowicki M (2020) COVID-19-related prejudice toward Asian medical students: A consequence of SARS-CoV-2 fears in Poland. J Infect Public Health, 13:873-876.

Schild L, Ling C, Blackburn J, Stringhini G, Zhang Y, Zannettou S (2020) "Go eat a bat, chang!": An early look on the emergence of sinophobic behavior on web communities in the face of COVID-19. arXiv; 2004.04046

SGDD (2020) COVID-19 Salgınının Türkiye'de Mülteciler Üzerindeki Etkilerinin Sektörel Analizi. Ankara, Sığınmacılar ve Göçmenlerle Dayanışma Derneği -ASAM.

Somvichian-Clausen. (2020) The coronavirus is causing an outbreak in America-of anti-Asian racism. https://thehill.com/changingamerica/respect/diversity-inclusion/480749-the-coronavirus-is-causing-an-outbreak-in-anti (Accessed 15.09.2020).

Stafford KE (2020) Predicting positive attitudes toward immigrants with altruism (Master's thesis). Lexington, University of Kentucky. Stanford News (2019) The power of language: How words shape people, culture. https://news.stanford.edu/2019/08/22/the-powerof-language-how-words-shape-people-culture (Accessed 15.09.2020).

Tafira K (2011) Is xenophobia racism? Anthropology Southern Africa, 34:114-121. 
Teixeira da Silva JA (2020) Stigmatization, discrimination, racism, injustice, and inequalities in the COVID-19 era. Int J Health Policy Manag, 9:484-485.

Üstübici A, Karadağ S (2020) Refugee Protection in Turkey during the First Phase of the COVID-19 Pandemic, Turkey Interim Report. İstanbul, Koç University.

Wardell-Ghirarduzzi MJ (2020) Racism against Asians during COVID-19. San Francisco, University of San Francisco.

WHO (World Health Organization) (2015) World Health Organization Best Practices for the Naming of New Human Infectious Diseases. Geneva, WHO.

Wong Y (2020) COVID-19 and Sinophobia in Singapore. Nanyang, Nanyang Technological University.

Yan H, Chen N, Naresh D (2020) What's spreading faster than coronavirus in the US? Racist assaults and ignorant attacks against Asians. https://www.cnn.com/2020/02/20/us/coronavirus-racist-attacks-against-asian-americans/index.html (Accessed 15.10.2020).

Zeng G, Wang L, Zhang Z (2020) Prejudice and xenophobia in COVID-19 research manuscripts. Nat Hum Behav, 4:879-879.

Ziems C, He B, Soni S, Kumar S (2020) Racism is a virus: Anti-Asian hate and counterhate in social media during the COVID-19 Crisis. arXiv; 2005.12423.

Zubashvili N (2020). Deconstructing and reconstructing attitudes towards immigrants: The case of Sweden (Master's thesis). Lund, Lund University.

Yazarların Katkıları: Yazar çalışmaya önemli bir bilimsel katkı sağladığını ve makalenin hazıllanmasında veya gözden geçirilmesinde yardımcı olduğunu kabul etmiştir.

Danışman Değerlendirmesi: Dış bağımsız.

Çıkar Çatışması: Yazar çıkar çatışması bildirmemiştir.

Finansal Destek: Yazar bu çalışma için finansal destek almadı̆̆ını beyan etmiştir.

Yazarın Notu: Bu çalışma 23-24 Ekim 2020 tarihinde İstanbul'da düzenlenen 7. Uluslararası Sosyal Beşeri ve Eğitim Bilimleri Kongresi'nde sözlü bildiri olarak sunulmuştur.

Authors Contributions: The author attest that he has made an important scientific contribution to the study and has assisted with the drafting or revising of the manuscript.

Peer-review: Externally peer-reviewed.

Conflict of Interest: No conflict of interest was declared by the authorss.

Financial Disclosure: The author declared that this study has received no financial support.

Acknowledgement: This study was presented in the ${ }^{\text {th }}$ International Congress on Social Sciences-Humanities and Education in Istanbul on 23-24 October 2020. 